Author: M Barnard

THE ROLE OF INTERNATIONAL SUSTAINABLE DEVELOPMENT LAW PRINCIPLES IN ENABLING EFFECTIVE RENEWABLE ENERGY POLICY - A SOUTH AFRICAN PERSPECTIVE

2012 VOLUME 15 No 2

http://dx.doi.org/10.4314/peli.v15i2.8 


\section{THE ROLE OF INTERNATIONAL SUSTAINABLE DEVELOPMENT LAW PRINCIPLES IN ENABLING EFFECTIVE RENEWABLE ENERGY POLICY - A SOUTH AFRICAN PERSPECTIVE}

M Barnard*

\section{Introduction}

Modern renewable energy ${ }^{1}$ is widely considered as being a basic ingredient for the promotion of sustainable development as the advantages connected with its implementation include, among others: the diversification of energy markets; securing long-term sustainable energy supplies; reducing atmospheric emissions; and enhancing the security of supply due to a reduction in imports. ${ }^{2}$ Taking these advantages into consideration it is surprising that renewable energy accounts for only $9 \%$ of South-Africa's total primary energy supply ${ }^{3}$ - the bulk of which is derived from the unsustainable harvesting and burning of traditional sources of biomass. ${ }^{4}$

The traditional use of biomass contributes directly to the production of detrimental side-effects such as environmental ${ }^{5}$ degradation and negative social ${ }^{6}$ impacts. The

* $\quad$ Michelle Barnard, LLB, LLM North-West University. Junior Lecturer and PhD-candidate at the North-West University (Potchefstroom Campus), 12128139@nwu.ac.za.

1 In the South African legal context, modern renewable energy is defined by the (then) Department of Minerals and Energy as energy which harnesses naturally occurring non-depletable sources of energy, such as solar, wind, biomass, hydro, tidal, wave, ocean current and geothermal energy, to produce electricity, gaseous and liquid fuels, heat or a combination of these energy types. See Paragraph 1.2 of the White Paper on Renewable Energy of 2003. Any further reference to renewable energy should be seen to infer modern renewable energy unless otherwise indicated.

2 Goldemberg J and Coelho ST "Renewable energy - traditional biomass vs modern biomass" 2004 Energy Policy 32711.

3 International Energy Agency Statistics, 2007 available at www.eia.gov/cabs/South_Africa.

4 See Paragraph 2 of the White Paper on Renewable Energy of 2003. While South-Africa has a $75 \%$ electrification rate, only $55 \%$ of the rural population has access to electricity. These communities depend heavily on the traditional use of biomass, which refers to the direct combustion of wood, charcoal, leaves, agricultural residue, and animal/human waste for their basic energy needs, which include cooking, drying and charcoal production. See Karakezi S, Lata K and Coelho ST "Traditional Biomass Energy: Improving its Use and Moving to Modern Energy Use" (Thematic Background Paper delivered at the International Conference for Renewable Energies in Bonn 2004); and Winkler H "Renewable energy policy in South Africa: policy options for renewable electricity" 2005 Energy Policy 3328.

5 The negative impacts include increased greenhouse gas emissions resulting from deforestation and environmental degradation See Bazilian M and Nussbaumer P "UNIDO Contribution to the 4th UN Conference on LDCs Energy Services" (Background Paper delivered at the 4th UN Conference on LDCs Energy Services in Istanbul, Turkey 9 - 13 May 2011) 4. 
reasons for the low rate of the introduction of renewable energy into South Africa include the high initial investment needed for its establishment, a lack of awareness regarding its benefits, and a lack of legal and regulatory measures regulating its implementation. ${ }^{7}$ It becomes apparent that in order to mitigate the negative effects of the traditional use of biomass as the primary energy source in South Africa, the focus must fall on promoting the implementation of modern renewable energy. This process of implementation needs to be regulated, which in turn necessitates the formulation of effective law and policy focused on sustainable development.

Recent policy developments in South Africa recognise the interconnectivity of the implementation of renewable energy and the promotion of sustainable development, and therefore propose to facilitate sustainable development via the implementation of renewable energy, among other methods. To this end, the White Paper on Renewable Energy of 2003 promotes increased access to affordable renewable energy in order to contribute to sustainable development. ${ }^{8}$ Furthermore, the 2008 first review of the National Energy Efficiency Strategy of the Republic of South-Africa of $2005^{9}$ (hereinafter referred to as EES 2008) states that in order for the country's renewable energy policy to be considered sustainable, it needs to facilitate development in the social, economic and environmental spheres. ${ }^{10}$ The question subsequently arises: how can the extent to which law and policy enable efficient, effective, fair and sustainable approaches to renewable energy be assessed?

The advent of the constitutional dispensation in South-Africa inevitably led to changes in the process of policy formulation. In its first energy policy drafted and

6 In Sub-Saharan Africa, where the traditional use of biomass as the primary energy source is most prevalent, the traditional use of biomass for cooking results in 1.5 million premature deaths per annum, usually of women and children, from debilitating respiratory infections. Furthermore, women are disproportionately burdened with the collection of biomass for burning, while children suffer with regard to poor lighting, making study after dark difficult. See The Energy Access Situation in Developing Countries: A Review focusing on the Least Developed Countries and Sub-Saharan Africa UNDP and WHO 200922 - 23; and Bazilian and Nussbaumer "UNIDO Contribution" 3.

7 See Paragraph 3.1.7 of the White Paper on Renewable Energy of 2003.

8 See Paragraph 1.1 of the White Paper on Renewable Energy of 2003.

9 GN 908 in GG 32342 of 26 June 2009.

10 Executive Summary of the EES $2008 \mathrm{ii.}$ 
published in terms of the provisions of the Constitution of the Republic of SouthAfrica, 1996 (hereinafter referred to as the Constitution), the White Paper on the Energy Policy of the Republic of South-Africa of 1998 (hereinafter referred to as the White Paper of 1998) states that greater emphasis should be placed on transparency, inclusiveness and accountability when formulating policy. ${ }^{11}$ The White Paper of 1998 furthermore acknowledges the fact that the process of policy formulation should not take place in a vacuum but should take into account countryspecific social, environmental and economic factors, if policy is to be able to facilitate sustainable development. ${ }^{12}$

In order to assess whether the promotion of sustainable development as an objective of any given activity has been attained or not, one must ascertain if the policy regulating the activity conforms to the principles underlying the objective. In other words, law and policy promoting the facilitation of sustainable development via the implementation of renewable energy must give effect to the principles underlying sustainable development. Accordingly, in order to ascertain whether or not South African renewable energy law and policy can successfully enable sustainable development via the increased implementation of renewable energy, a specific methodology has to be used.

Sustainable development law (SDL) has been described as a body of international legal principles which address the areas of intersection between international economic law, international environmental law and international social law. ${ }^{13}$ SDL revolves around cooperative international efforts to identify and distil general substantive and procedural principles. ${ }^{14}$ A prime example is the seven principles of international law related to sustainable development as identified by the International

11 Paragraph 3.1 of the White Paper of 1998.

12 Paragraph 3.2 of the White Paper of 1998.

13 Cordonier Segger MC "Significant Developments on Sustainable Development Law and Governance: A Proposal" 2004 United Nations Sustainable Development Journal Vol 28 Issue 1 62.

14 See United Nations, Report of the Expert Group Meeting on Identification of Principles in International Law for Sustainable Development (UN Secretariat, September 1995). For further reading on the subject see also Gehring MW and Gordonier Segger MC Sustainable Development in World Trade Law (Kluwer Law International, Netherlands, 2005) 6. 
Law Association Committee on Legal Aspects, contained in its 2002 New Delhi Declaration. ${ }^{15}$ It is the opinion of the author that the New Delhi principles represent an encompassing, albeit not exhaustive SDL framework within which renewable energy law and policy should be formulated and implemented to effectively promote sustainable development. Accordingly, the New Delhi principles will be used as the basis against which to test existing South-African renewable energy law and policy in order to establish if it gives effect to the objective of the promotion of sustainable development.

This principled qualitative policy assessment should serve as a sound basis for establishing a common, yet flexible ground for valid solutions to challenges surrounding sustainable renewable energy law and policy - the assumption being, that a principled assessment of national law will ensure a holistic, qualitative debate on how certain elements of a policy are designed to support sustainable development. ${ }^{16}$ The assessment envisaged by this article should by no means be construed as a mere "check list" by which to judge to what extent South African law and policy contain the New Delhi principles - although this will be touched upon. The principled assessment of South African renewable energy law and policy should rather have the effect of ascertaining if the law and policy are capable of facilitating sustainable development.

In so doing, this paper will engage in a brief discussion of the SDL principles contained in the New Delhi Declaration. This will be followed by an analysis of specific South African renewable energy law and policy documents as well as the national sustainable development framework and strategy. A conclusion will then be reached regarding the extent to which each of the New Delhi principles is evident in South African law and policy and whether or not the law and policy serve to promote sustainable development.

15 Resolution of the 70th Conference of the International Law Association in New Delhi, India, 2 - 6 April 2002. Hereinafter referred to as the New Delhi Declaration or ILA Resolution 3/2002.

16 Goepel M "Formulating Future Just Policies: Applying the Delhi Sustainable Law Principles" 2010 Sustainability 21695. 


\section{The Principles of International Law Relating to Sustainable Development ${ }^{17}$}

From the outset it should be made clear that while the author does take cognisance of relevant contemporary international legal developments' contribution to the ongoing sustainable development debate ${ }^{18}$ the purview and purpose of this article do not include an analysis of their provisions.

Emerging mainly from "soft law instruments" such as declarations, SDL principles have a certain persuasive force, ${ }^{19}$ whilst showing a normative character in international law in the sense that they create obligations or rights for the states that are bound by them. ${ }^{20} \mathrm{SDL}$ principles may also prove helpful in resolving conflicts related to sustainable development and support the balanced integration of laws and policies at the intersection of international environmental, social and economic law. ${ }^{21}$

In this regard, the New Delhi Declaration identifies seven SDL principles distilled from several global-scale processes spanning four decades. ${ }^{22}$ Taking into

17 ILA Resolution 3/2002. The term "New Delhi principles" will also be used when referring to the principles of international law related to sustainable development contained in the New Delhi Declaration.

18 Most notably, the statements and declarations emerging from the UN Climate Change Conference of Parties (COP), which include among others: The Bali Action Plan (UNFCCC, Decision 1/CP.13); the Copenhagen Accord (UNFCCC, Decision 2/CP.15) and the Cancun Agreements (UNFCCC, Decision 1/CP.16). These instruments focus predominantly on the role of the increased use of renewable energy in mitigating the effects of climate change - one of the major developmental challenges currently faced by humankind.

19 Lowe V "Sustainable Development and Unsustainable Arguments" in Boyle A and Freestone D International Law and Sustainable Development: Past Achievements and Future Challenges (Oxford University Press, 1999) 16.

20 French D International Law and Policy of Sustainable Development (Manchester University Press, 2005) 97.

21 Cordonier Segger MC and Khalfan AL Sustainable Development Law: Principles, Practices and Prospects (Oxford University Press 2004) Part 41.

22 The most important international policy-making processes leading up to the New Delhi Declaration include: the Stockholm Declaration of the United Nations Conference on Human Environment of 1972 (hereinafter referred to as the Stockholm Declaration); the Brundtland Report; and the Rio Declaration on Environment and Development of 1992 (hereinafter referred to as the Rio Declaration), which also contains Agenda 21. The Brundtland Report contains 22 legal principles which were echoed in the 27 principles contained in the Rio Declaration. The Rio Declaration was followed by the Report of the Expert Group Meeting on Identification of Principles of International Law for Sustainable Development, released by the UN Commission on Sustainable Development in 1995. This Report led to the drafting of the New Delhi Declaration. See Goepel 2010 Sustainability 1697. 
consideration the comprehensive and detailed study and analysis undertaken by the ILA in drafting the New Delhi Declaration, as well as the relatively normative clarity of their findings, the New Delhi principles are widely considered to provide the most current benchmark of guiding principles on international law on sustainable development. $^{23}$ They are not exhaustive and several are not yet recognised as binding rules of customary international law. They do, however, provide a normative context for the framing of sound policy and law in the field of sustainable development. $^{24}$ It is accordingly submitted that these principles should form the starting point in a principled assessment of any national law and/or policy regarding any activity related to sustainable development. ${ }^{25}$ In order to be able to assess South African renewable energy law and policy in this manner, a brief and generic overview of the principles contained in the New Delhi Declaration should first take place.

\subsection{The duty of states to ensure the sustainable use of natural resources}

In accordance with the provisions contained in the Rio Declaration ${ }^{26}$ as well as the Stockholm Declaration, ${ }^{27}$ resource sovereignty must be seen through the lens of sustainable development. ${ }^{28}$ This principle obliges States to manage natural resources in a rational, sustainable and safe way, taking into account the needs of future generations in determining the rate of use of natural resources, to ensure that

23 Cordonier Segger MC and Rana R Selecting Best Policies and Laws for Future Generations Centre for International Sustainable Development Law Working Paper and Worked Examples (Montreal Canada, 2008) 10.

24 Goepel 2010 Sustainability 1698.

25 As stated previously, the author does acknowledge that other instruments and documents related to sustainable development exist - see footnote 18 above. It is submitted, however, that applying a "principled assessment" at the hand of the New Delhi Declaration will provide a holistic, qualitative and integrated analysis of how certain elements of national law and policy are seen to support sustainable development.

26 Report of the United Nations Conference on Environment and Development U.N.Doc.A/CONF.151/6/Rev.1 (1992).

27 U.N. Doc.A/CONF.48/14/Rev.1, 11 I.L.M.

28 Principle 21 of the Stockholm Declaration provides for States to have the right to exploit their own resources pursuant to their own environmental policies. Principle 2 of the Rio Declaration goes a step further by placing the exercise of resource sovereignty not only in an environmental but also a developmental context. See Schrijver NJ "Permanent Sovereignty over Natural Resources" in Wolfrum R (ed) Max Planck Encyclopedia of Public International Law (Oxford University Press 2010) $5-6$. 
all people (including indigenous people and future generations) benefit from the exploitation of resources, and to have due care for the environment ${ }^{29}$. On a national level, the main problem related to this principle is the need to be able to identify what the term "sustainable use" entails. It is submitted that the definition of sustainable development should be applied in this regard. In other words, the "sustainable use" of natural resources should be seen to entail using resources in such as fashion as to meet the needs of the present without compromising the ability of future generations to meet their own needs. ${ }^{30}$ The challenges connected with defining this principle should, however, not negate the value of the principle itself, which is to encourage states to seek appropriate regulatory instruments and practices regarding the "sustainable management" ${ }^{31}$ of the use of natural resources.

\subsection{The principle of equity and the eradication of poverty}

Equity and poverty eradication are key principles of international sustainable development law. References to this principle made in international instruments in the fields of environmental, developmental, human rights and economic law are influenced greatly by the definition of sustainable development (mentioned in paragraph 2.1 above). ${ }^{32}$ The principle of poverty eradication enjoys attention in terms of the provisions of the Johannesburg Plan of Implementation ${ }^{33}$ (hereinafter referred to as $\mathrm{JPI}$ ) and the International Covenant on Economic, Social and Cultural Rights $^{34}$ (hereinafter referred to as the ICESR). According to the JPI, poverty has

29 Schrijver NJ Permanent Sovereignty over Natural Resources: Balancing Rights and Duties (Cambridge University Press 1997) 8 - 9.

30 World Commission on Environment and Development, Our Common Future (Oxford University Press 1987) 13.

31 The "sustainable management" of the use of natural resources should be seen to include, among others: long-term natural resource planning and management systems, and modelling to estimate or predict "sustained yield" or the thresholds for resource collapse, as well as joint international monitoring systems.

32 Hepburn $\mathrm{J}$ and Khalfan AL The Principle of Equity and the Eradication of Poverty Centre for International Sustainable Development Law Draft Working Paper (Oxford 2005) 3 available at www.cisdl.org/pdf/sdl/SDL_Equity.pdf.

33 Report of the World Summit on Sustainable Development, Johannesburg, South Africa, 26 Aug 4 Sept 2002, UN Doc. A/CONF.199/20 [JPOI].

3419 December 1966, 993 U.N.T.S. 3. 
various manifestations ${ }^{35}$ and the eradication of poverty (alongside other objectives) is essential to the fulfilment of the goal of sustainable development. ${ }^{36}$ The ICESR, on the other hand, defines poverty as "the lack of basic capabilities to live in dignity" $^{37}$ and states that rights connected to the principle of poverty eradication should refer to basic human rights. ${ }^{38}$

With reference to the principle of equity, it is common ground that the resources of the earth belong to all generations. Being a principle central to the attainment of sustainable development, equity should be seen to include both inter-generational equity $^{39}$ and intra-generational equity. ${ }^{40}$ This principle, which is closely related to the sustainable use of natural resources, demands that, while the present generation has a right to use and enjoy the resources of the earth, it is under an obligation to take into account the long-term impact of its activities and to sustain the resource base and the global environment for the benefit of future generations of humankind.

\subsection{The principle of common but differentiated responsibilities}

The principle of common but differentiated responsibilities evolved from the notion of the common heritage of mankind and is a particular manifestation of the general

35 Poverty has various manifestations, including a lack of income and productive resources sufficient to ensure sustainable livelihoods; hunger and malnutrition; ill health; limited or lack of access to education and other basic services; increased morbidity and mortality from illness; homelessness and inadequate housing; unsafe environments; and social discrimination and exclusion. It is also characterised by a lack of participation in decision-making and in civil, social and cultural life. See Chapter II of the JPI.

36 Paragraph 1 of the JPI.

37 Paragraphs 7 and 8 of the Committee on Economic, Social and Cultural Rights, Poverty and the International Covenant on Economic, Social and Cultural Rights, UN ESCOR, 2001, UN Doc E/C.12/2001/10.

38 These include the right to health, education, development, food, water, housing, and other related rights contained in the ICESCR.

39 This principle demands that every generation, by virtue of its own effort and responsibility, must secure a proportionate share in the common good of the human species. See Aguis $\mathrm{E}$ "Obligations of Justice Towards Future Generations: A Revolution in Social and Legal Thought" in Aguis E et al (eds) Future Generations and International Law (London, Earthscan Publications, 1998) 10.

40 The term can be formulated as the obligation "to ensure a just allocation of the utilisation of resources among human members of the present generation, both at the domestic and global levels". See Hepburn and Khalfan CISDL Draft Working Paper 5. 
principles of equity in international law. ${ }^{41}$ In terms of the broad interpretation afforded to the principle in terms of the New Delhi Declaration, it entails "a duty to cooperate in the achievement of global sustainable development". The New Delhi Declaration furthermore acknowledges the different roles developed and developing States play in regard to global environmental problems, and addresses their economic and technical capacity to address these issues. ${ }^{42}$ In essence therefore, this principle consists of two fundamental components, namely common responsibility on the one hand and differentiated responsibility on the other.

The common responsibility component deals with the duty resting on States to protect the environment, or parts of it, at the national, regional and global levels. ${ }^{43}$ The common responsibility resting on States comes into play where resources are shared; under the control of no state; or under the sovereign control of a state but subject to a common legal interest such as biodiversity. ${ }^{44}$ The reference to differentiated responsibility has to do with the discrepancies in the capacities ${ }^{45}$ of developing and developed States to contribute towards environmental protection. This translates into the setting of differentiated environmental standards on the basis of a range of factors, including the future economic development of countries and their historic contributions to the creation of any given environmental problem. ${ }^{46}$ Differentiated responsibility therefore aims to promote substantive equality among developing and developed States, rather than to impose mere formal equality.

The practical implementation of the principle as a whole should have the following consequence, namely that States will have different environmental standards imposed upon them in order that they may exercise the common responsibility of protecting shared environmental resources.

41 Sands P Principles of International Environmental Law: Frameworks, Standards and Implementation 2nd ed (Cambridge University Press 2005) 217.

42 The Principle of Common but Differentiated Responsibilities: Origins and Scope Centre for International Sustainable Development Law Legal Brief available at www.cisdl.org /pdf/brief_common.pdf.

43 Hepburn J and Ahmad I The Principle of Common but Differentiated Responsibilities Centre for International Sustainable Development Law Draft Working Paper (Oxford 2005) 3 available at http://www.scribd.com/doc/51595811/SDL-Common-but-Diff.

44 CISDL Legal Brief www.cisdl.org/pdf/brief_common.pdf

45 Capacity should be seen to include factors such as, but not limited to, economic, infrastructure, expertise, technology and research capabilities.

46 CISDL Legal Brief www.cisdl.org/pdf/brief_common.pdf. 


\subsection{The principle of the precautionary approach to human health, natural resources and ecosystems ${ }^{47}$}

In terms of the New Delhi Declaration, the precautionary principle entails that the agent of activities which might lead to significant, serious or irreversible harm is obliged to take measures to prevent this damage even if there is a lack of full scientific certainty as to the existence and severity of the risk. ${ }^{48}$ The precautionary principle is therefore a response to an important problem in decision-making, namely the absence of complete scientific information concerning the environmental consequences of a particular activity. ${ }^{49}$ It could therefore also be said that the principle of precaution is based on the premise that harm may be prevented before it occurs by means of governmental decision-making based on scientific data, and the notion that the precautionary measures taken should be in proportion with the potential damage. ${ }^{50}$ The precautionary principle contained in the New Delhi Declaration builds upon Principle 15 of the Rio Declaration, which states that where serious or irreversible damage threatens, lack of full scientific certainty shall not be used as a reason for postponing the taking of cost-effective measures to prevent environmental degradation. ${ }^{51}$ While the Rio Declaration is widely considered an authoritative reference point for the precautionary principle in international law, it seems to focus on the prevention of environmental degradation, omitting reference to social and economic degradation. The broader formulation of the precautionary

47 Hereinafter the term "precautionary principle" will be used when referring to the principle of the precautionary approach to human health, natural resources and ecosystems.

48 Hepburn J, Cordonier-Segger MC and Gehring M The Principle of the Precautionary Approach to Human Health, Natural Resources and Ecosystems Centre for International Sustainable Development Law Draft Working Paper (Oxford 2005) 3 available at www.cisdl.org/pdf/sdl/SDL_Precaution.pdf.

49 Hepburn J, Cordonier-Segger MC and Gehring M The Principle of the Precautionary Approach to Human Health, Natural Resources and Ecosystems Centre for International Sustainable Development Law Draft Working Paper (Oxford 2005) 3 available at www.cisdl.org/pdf/sdl/SDL_Precaution.pdf date of use 13 July 2011.

50 Hickey,Jr JE and Walker VR "Refining the Precautionary Principle in International Environmental Law" 1995 Virginia Law Journal $14 \quad 436$ available at http://heinonline.org/HOL/Page?handle=hein.journals/velj14\&div=17\&g_sent=1\&collection=journ als.

51 U.N.Doc.A/CONF.151/6/Rev.1 (1992) 3. 
principle contained in the New Delhi Declaration, however, moves away from the traditional environmentally based formulation towards a formulation focused on the environment as well as human health. In terms of the New Delhi Declaration, a precautionary approach with regard to human health, environmental protection and the sustainable utilization of natural resources should include accountability for the harm caused, planning based on clear criteria and well defined goals, and the consideration in an environmental impact assessment of all possible means to prevent harm from occurring. ${ }^{52}$

\subsection{The principle of public participation and access to information and justice}

The participation of the public ${ }^{53}$ in policy formulation is essential to sustainable development and good governance as it is a condition of responsive, transparent and accountable governance. This principle enjoys substantial support in various international legal instruments ${ }^{54}$ and finds its basis in the fundamental human right ${ }^{55}$ to hold and express opinions and to seek, receive and impart ideas. In order to

52 Cordonier Segger and Khalfan Sustainable Development Law Part 43.

53 The public, as understood in the context of this principle, is a community of people and should not be seen as an explicit reference to the public of a certain State, nor of people possessing citizenship rights to a specific place. The public is differentiated from the State in that people can be State actors and operate within the interests of that State, while at the same time belonging to the public, where they can freely express their own ideas. See Hepburn and Khalfan CISDL Working Draft Paper 3. In the context of sustainable development, the "public" should therefore be seen to include individuals, trade unions, non-governmental organisations, business organisations and other civil society organisations.

54 In terms of article 12 of the International Covenant on Economic, Social and Cultural Rights of 1966 (which entered into force in 1976), every citizen has the right to participate in "the conduct of public affairs, directly or through freely chosen representatives...". The Covenant also illustrates the importance of access to information, by stating in article 13 that "education shall enable all persons to participate effectively in a free society". Reference to this principle can also be found in the preamble of the Stockholm Declaration; article 1 of the UN Declaration on the Right to Development; and principles 5, 10, $19-21$ of the Rio Declaration.

55 The UN Universal Declaration of Human Rights of 1948 refers in article 21 to everyone's "right to take part in the government of his country, directly or through freely chosen representatives", the "right of equal access to public service in his country" and that "the will of the people shall be the basis of the authority of government". 
facilitate development of educated and informed opinions, access to appropriate, comprehensible and timely information is critical. ${ }^{56}$

Taking this definition into consideration the principle of public participation and access to information and justice can be seen as consisting of three key elements. In the first instance, public participation is recognised as a human right of expression. Viewed as such, it is especially significant for previously disadvantaged groups such as women to be accorded the opportunity to participate in official socioeconomic development, decision-making processes and activities that directly affect their lives and well-being. ${ }^{57}$ The second element is related to the public's ability to formulate and hold informed opinions and expressions. In order to do so the public must be provided with, or at least have access to adequate information concerning the decisions and activities of governments and commerce. This applies to information specifically relating to the sustainable use of natural resources and the protection of the environment, with due regard to the financial burdens on those seeking the information. ${ }^{58}$ The third and final aspect of this principle is access to justice, which refers to instances where rights or entitlements have allegedly been violated. ${ }^{59}$ Access to justice should have the effect of ensuring that violated parties have access to judicial or administrative relief.

In the context of national law, public participation and access to information hinges upon ensuring that all persons have access to appropriate, comprehensible and timely information held by governments on economic and social policies regarding the sustainable use of natural resources and the protection of the environment. Furthermore, access to justice would entail having access to appropriate judicial or administrative relief where parties have been denied their right to participation or access to information.

56 Bottriel K and Cordonier Segger MC The Principle of Public Participation and Access to Information and Justice Centre for International Sustainable Development Law Draft Working Paper (Oxford 2005) 3.

57 Bottriel CISDL Draft Working Paper 3.

58 Bottriel CISDL Draft Working Paper 4.

59 Bottriel CISDL Draft Working Paper 4. 


\subsection{The principle of good governance}

The principle of good governance is perceived as a normative principle of administrative law which obliges the State to perform its functions in a manner that promotes the values of efficiency, non-corruptibility, and responsiveness to civil society. ${ }^{60}$ While government is not obliged to substantively deliver any public goods, it must ensure that the processes for the identification and delivery of such goods are concrete in terms of (i) being responsive to public demands; (ii) being transparent in the allocation of resources; and (iii) being equitable in the distribution of goods. ${ }^{61}$ The United Nations Millennium Declaration, $2000^{62}$ draws the link between transparency as an element of good governance on the one hand and the promotion of sustainable development and the achievement of the Millennium Development Goals (MDGs) on the other. ${ }^{63}$ Referring to the correlation between good governance and human rights, the United Nations High Commissioner for Human Rights (OHCHR) identifies five key characteristics of the concept of good governance, namely transparency, responsibility, accountability, participation, and responsiveness by the State to the needs of the people. ${ }^{64}$

According to the New Delhi Declaration, good governance is essential to the progressive development and codification of international law relating to sustainable development. ${ }^{65}$ The New Delhi Declaration commits States and international organizations to adopt democratic and transparent decision-making procedures and financial accountability; take effective measures to combat corruption; respect the

60 Rosenau JN Along the Domestic-Foreign Frontier: Exploring Governance in a Turbulent World 1st ed (Cambridge University Press, 1997).

61 Chowdbury N and Skarstedt CE The Principle of Good Governance Centre for International Sustainable Development Law Draft Working Paper (Oxford 2005) 4.

62 GA Res. 55/9, UN GAOR, 2000.

63 Paragraph 13 of the Millennium Declaration of 2000.

64 Office of the High Commissioner for Human Rights, The role of good governance in the promotion of human rights, Commission on Human Rights resolution 2001/72 available at www.ohchr.org/english/issues/development/governance/compilation/forside $02 . \mathrm{html}$.

65 Cordonier Segger and Khalfan Sustainable Development Law 171. 
principles of due process; observe the rule of law and human rights; and implement an internationally acceptable public procurement approach. ${ }^{66}$

At the domestic level, States commit themselves to sound environmental, social and economic policies, democratic institutions responsive to the needs of the people, the rule of law, anti-corruption measures, gender equality and an enabling environment. ${ }^{67}$ This principle therefore binds States to democratic and transparent decision-making, anti-corruption, respect for the rule of law and human rights, and is closely related to the principle of participation, access to information and justice.

\subsection{The principle of integration and interrelationship in relation to human rights and social, economic and environmental objectives ${ }^{68}$}

The notions of integration and interrelationship lie at the very core of the concept of sustainable development and could therefore be described as being fundamental to its existence. ${ }^{69}$ This is especially evident when one considers the definition of International Sustainable Development Law (ISDL). ISDL can be defined as a body of international legal principles and treaties which address the areas of intersection between international economic law, international environmental law and international social law focused on development that can last. ${ }^{70}$ The interrelationship among the three pillars of sustainable development law (SDL) influences and informs the elaboration, interpretation and application of other principles of SDL by providing a conceptual framework for integrated thinking in international law relating to sustainable development. ${ }^{71}$ In the Case Concerning the Gabcikovo-Nagymaros

66 Paragraph 6(1) New Delhi Declaration.

67 JPI paragraph I 4.

68 Hereinafter the term "integration principle" will be used when referring to the principle of integration and interrelationship in relation to human rights and social, economic and environmental objectives.

69 Jodion A The Principle of Integration and the Interrelationship in Relation to Human Rights and Social, Economic and Environmental Objectives Centre for International Sustainable Development Law (Oxford 2005) 1.

70 Cordonier Segger and Khalfan Sustainable Development Law 103.

71 Cordonier Segger and Khalfan Sustainable Development Law 102. 
Project $^{72}$ the International Court of Justice (ICJ) highlights the importance of the integration principle, stating in its judgment that the "need to reconcile economic development with protection of the environment is aptly expressed in the concept of sustainable development." ${ }^{73}$ It could be argued that the integration principle should accordingly be labelled as a "core principle" of sustainable development placing it in the same category as the application of equity between States, the consideration of the needs of future generations, and the non-exhaustion of renewable energy sources. $^{74}$

Taking all of the aforementioned into consideration, the definition of the integration principle should be seen to consist of two main components, namely the existence of linkages between the various spheres of international law bearing on sustainable development and the integration of the norms and principles emanating from these spheres. In general terms, the integration principle implies the need for States to take into account the interdependence of economic, environmental, social and human rights issues and furthermore entails the necessity of reconciling, accommodating and harmonising the priorities, concerns and norms emanating from each area. $^{75}$

In order to ascertain the extent to which South Africa integrates the New Delhi principles in its renewable energy law and policy, the following methodology will be applied. The background to the historical development of the South African renewable energy policy will be discussed first, and South African law and policy will be analysed afterwards with specific reference to the principles contained therein. These principles will then be categorized in terms of the seven principles contained in the New Delhi Declaration in order to reach a conclusion on whether or not South African renewable energy law and policy facilitate sustainable development.

721997 ICJ Rep. 78140.

731997 ICJ Rep. 781409.

74 Sands distinguishes between core principles of sustainable development and principles drawn from other areas of international law. He identifies the core principles as principles that seem to be inherent in the concept of sustainable development and that point to the limits that must be placed on the use of natural resources while principles drawn from other areas of international law are intended to provide assistance in achieving sustainable development. See Sands $\mathrm{P}$ "International Law in the Field of Sustainable Development" 1994 British Yearbook of International Law 65338.

75 Jodion CISDL Draft Working Paper 4 - 5. 


\section{Renewable energy law and policy in South-Africa}

South African renewable energy law and policy consist of various pieces of legislation and policy documents cutting across a wide range of issues related to renewable energy. These include issues such as pricing and the licensing requirements, ${ }^{76}$ procurement, ${ }^{77}$ the mitigating effects of the implementation of renewable energy, ${ }^{78}$ the establishment of a national energy regulator, ${ }^{79}$ and fiscal matters such as tax and revenue. ${ }^{80}$ It is not the purpose of this article to provide a discussion on each of these issues and the way in which they relate to or fit into South African renewable energy law and policy. Rather, the author's focus is upon those legislative measures and policy documents stipulating the inter-connectivity of the promotion of the sustainable development of the country on the one hand and the implementation of renewable energy on the other.

\subsection{The Constitution of the Republic of South-Africa, 1996}

76 Renewable Energy Feed-in-Tariff Regulatory Guidelines of 2009.

77 Renewable Energy Independent Power Producer Programme (2011).

78 Medium Term Risk Mitigation Project for Electricity in South Africa (2010 - 2016) which is also closely related to the provisions of the Integrated Resource Plan for Electricity $(2010-2030)$. See also the Biofuels Industrial Strategy for the Republic of South Africa of 2006; the National Climate Change Response Green Paper of 2010 and the National Climate Change Response White Paper of 2011.

79 National Energy Regulator Act 40 of 2004. Related to Act 40 of 2004 are the provisions contained in both the Electricity Regulation Act 4 of 2006 and the Independent System and Market Operator Establishment Bill GN 290 in GG 34289 of 13 May 2011.

80 A Framework for Considering Market Based Instruments to support Environmental Fiscal Reform in South Africa National Treasury Draft Policy Paper on Market Based Instruments of 2006 and the Carbon Tax Policy Paper of 2010. 
The Constitution of the Republic of South-Africa, 1996 (hereinafter referred to as the Constitution) recognises the correlation between the regulation of environmental protection and the promotion of sustainable development. In terms of section 24 , the State must establish and implement reasonable legislative measures to promote sustainable development and the sustainable use of natural resources while providing for the protection of the environment for the benefit of the present and future generations. ${ }^{81}$ It is clear that the legislative measures mandated by section 24 of the Constitution should be geared towards the facilitation of the promotion of sustainable development. In any instance where the promotion of sustainable development is mentioned as an objective of an activity, note should be taken of the international principles related to sustainable development. It could therefore be argued that the international sustainable development law principles should by implication be applied not only in the process of formulating the national law and policy referred to in the Constitution but should also be contained in the legislative measures resulting from the formulation process.

It is noteworthy that while the New Delhi Declaration did not yet exist at the time of the drafting of section 24 of the Constitution, the provision nonetheless makes mention of two principles later to be included in the New Delhi Declaration. Section 24 refers to the principle of equity as well as the principle of the sustainable use of natural resources, both of which were contained in other international legal instruments, such as the Brundtland Report, the Rio Declaration and the Stockholm Declaration. $^{82}$

\subsection{White Paper on the Energy Policy of the Republic of South Africa of 1998}

The White Paper on the Energy Policy of the Republic of South Africa of 1998 (hereinafter referred to as the White Paper of 1998) was the first policy document

81 Section 24(b) of the Constitution of the Republic of South Africa of 1996

82 See paragraphs 2.1 and 2.2 above. 
relating to energy to be drafted in terms of section 24 of the Constitution. The White Paper of 1998 recognises the fact that the context as well as the general approach to policy formulation has changed due to the democratisation of the country. ${ }^{83}$ The energy policy contained in the White Paper of 1998 and the process of policy formulation prescribed therein therefore promote sustainable development by giving effect to the principles of equity and the sustainable use of natural resources provided for by section 24 of the Constitution.

The White Paper of 1998 stresses the importance of the principles of transparency; inclusiveness and the accountability of elected officials and states that these principles should be applied to every aspect ${ }^{84}$ of the formulation process. ${ }^{85}$ The principles referred to relate to the process surrounding the formulation of energy law and policy and therefore set the tone for the principles to be contained in resulting law and policy. The principles of accountability, transparency and inclusiveness should therefore not be applied only during the formulation process but should also be contained in the resulting policy documents.

It should once again be noted that while the New Delhi Declaration had not yet been drafted at the time of the White Paper of 1998, many of the principles referred to in the White Paper of 1998 would later be contained in the New Delhi Declaration. The ISDL principle of good governance ${ }^{86}$ and the principle of public participation and access to information and justice ${ }^{87}$ relate directly to the principles of transparency, inclusiveness and the accountability of elected officials contained in the White Paper of 1998 . Its objectives ${ }^{88}$ and priorities ${ }^{89}$ in turn relate broadly to the principles of equity and the eradication of poverty. ${ }^{90}$

83 Paragraph 3.1 of the White Paper of 1998.

84 These aspects include making government's approach to energy policy formulation more transparent, building public confidence in the policy formulation process, clarifying accountability and organizational roles, communicating policy in a manner which is clear and understandable for all, and integrating various government policies. See paragraph 4.2 of the White Paper of 1998.

85 Executive Summary of the White Paper of 1998.

86 Principle 6 of the New Delhi Declaration. See paragraph 2.6 above.

87 Principle 5 of the New Delhi Declaration. See paragraph 2.5 above.

88 The objectives contained in the Energy Policy include increased access to affordable energy services, improving energy governance, stimulating economic development, managing energy$224 / 569$ 
When assessing the White Paper of 1998 in terms of the extent to which it contains the New Delhi principles, one observes that while it does not cater for every single principle set out in the New Delhi Declaration it serves as a solid basis for a principled approach to policy formulation.

\subsection{The White Paper on Renewable Energy of 2003}

Echoing the provisions regarding the sustainable use of national resources contained in the Constitution, the White Paper of 1998 states that an equitable level of national resources must be invested in renewable technologies. ${ }^{91}$ Subsequently, the White Paper on Renewable Energy of 2003 (hereinafter referred to as White Paper of 2003) was drafted. The White Paper of 2003 identifies sustainable development $^{92}$ as one of the essential elements of the national renewable energy policy - arguably making the New Delhi principles applicable to the formulation process and the policy itself. It states that while its overarching principles are the same as those contained in the Constitution as well as those in the White Paper of $1998,{ }^{93}$ further key policy principles ${ }^{94}$ are identified specifically for the renewable energy policy.

The policy principles contained in the White Paper of 2003 refer specifically to the renewable energy policy, and include the full-cost accounting principle; the principle

related environment and health impacts, and securing supply through diversity. See Paragraph 3.2.2 of the White Paper of 1998.

89 The objectives of the White Paper of 1998 give rise to priority being given to improving the access to energy of previously disadvantaged groups in order to facilitate sustainable development and the eradication of poverty. See Paragraph 3.1 of the White Paper of 1998.

90 Principle 2 of the New Delhi Declaration. See paragraph 2.2 above.

91 Paragraph 7.7 of the White Paper of 1998.

92 Sustainable development is defined as "the integration of social, economic and environmental factors into planning, implementation and decision-making so as to ensure that development serves present and future generations". See Paragraph 7.1 of the White Paper of 2003.

93 These principles govern the accountability of elected officials, inclusiveness and transparency. See paragraphs 3.1 and 3.2 above.

94 The policy principles are the fundamental premises that Governments will use to apply, develop and test its policy and its subsequent actions, including decision-making, legislation, regulation and enforcement with specific reference to renewable energy. See Paragraph 6 of the White Paper of 2003. 
of equity; the principle of global and international cooperation and responsibilities; the principle guiding the allocation of functions; and the principle of public participation.

The full-cost accounting principle entails that pricing will take into account the full economic, social and environmental costs as well as the benefits connected with the implementation of a renewable energy scheme. This principle relates to the principle of integration and interrelationship in relation to human rights and the social, economic and environmental objectives ${ }^{95}$ contained in the New Delhi Declaration, as it makes clear reference to the interrelationship of the three elements related to sustainable development. ${ }^{96}$ It could be argued that the full-cost accounting principle also relates to the precautionary approach to human health and the environment ${ }^{97}$ as full-cost accounting entails that both the impacts as well as the benefits related to the intended activity be taken into consideration before action is taken. ${ }^{98}$

The principle of equity ${ }^{99}$ entails that equitable access to basic services (to meet people's needs and ensure their wellbeing) must be ensured, while protecting future generations' ability to enjoy the same rights. This principle once again relates to the international sustainable development principle of equity and the eradication of poverty. ${ }^{100}$

The principle of global and international cooperation and responsibilities ${ }^{101}$ has the effect of ensuring that government considers relevant regional as well as international policy principles when formulating national renewable energy policy. This principle relates to the principle of common but differentiated responsibilities ${ }^{102}$ in ensuring that regional responsibilities are taken into account, and places emphasis

95 Principle 7 of the New Delhi Declaration. See paragraph 2.7 above.

96 See paragraph 2.7 above.

97 Principle 4 of the New Delhi Declaration. See 2.4 above.

98 See paragraph 2.4 above.

99 Paragraph 6 of the White Paper of 200326.

100 Principle 2 of the New Delhi Declaration. See 2.2 above.

101 Paragraph 6 of the White Paper of 200326.

102 Principle 3 of the New Delhi Declaration. See paragraph 2.3 above. 
on broad cooperation. It also gives effect to the principle of integration as contained in the New Delhi Declaration. ${ }^{103}$

In terms of the principle guiding the allocation of functions, ${ }^{104}$ government must apply the provisions of the Constitution regarding the duties of the different spheres and institutions of government - this, therefore, relates to the principle of good governance ${ }^{105}$ in that it allocates duties to specific institutions and therefore creates accountability.

In the final instance, participation as a policy principle ${ }^{106}$ demands that government encourage the inclusion of all stakeholders in energy governance, with the aim of achieving equitable and effective participation. This relates once again to both the principles of good governance ${ }^{107}$ on the one hand, and public participation and access to information and justice on the other. ${ }^{108}$

The policy principles contained in the White Paper of 2003 complement and give effectto the principles contained in the New Delhi Declaration as discussed in the foregoing paragraphs. One may even argue that substantive meaning is given to the New Delhi principles. Elements of good governance are codified and given substance, for example. The White Paper of 2003 is an outstanding example of how a principled approach to law and policy formulation can result in law and policy giving effect to the objective proposed by the principles underlying the policy. In practical terms, the fact that a number of ISDL principles were applied in the formulation of the White Paper of 2003 led to the subsequent inclusion of these and other ISDL principles in the White Paper of 2003 itself. In terms of a principled assessment based on the New Delhi principles, the White Paper of 2003 can therefore be seen to theoretically effect the objective of promoting sustainable development.

\subsection{National Energy Act 34 of 2008}

103 Principle 7 of the New Delhi Declaration. See paragraph 2.7 above.

104 Paragraph 6 of the White Paper of 200326.

105 Principle 6 of the New Delhi Declaration. See paragraph 2.6 above.

106 Paragraph 6 of the White Paper of 200326.

107 Principle 6 of the New Delhi Declaration. See paragraph 2.6 above.

108 Principle 5 of the New Delhi Declaration. See paragraph 2.5 above.

$227 / 569$ 
In its preamble, the National Energy Act 34 of 2008 (hereinafter referred to as Act 34 of 2008) states that increased generation and consumption of renewable energy will be an important contributing factor towards attaining the objective of promoting sustainable development. ${ }^{109}$ This necessitates the formulation of an integrated and sustainable energy plan which should focus on issues related to energy ${ }^{110}$ while taking into account various economic, environmental and social factors. ${ }^{111}$ Act 34 of 2008 makes note of some principles to be taken into account when formulating policy regulating a national integrated energy plan. These principles are the optimal use of indigenous and regional energy resources, a balance between supply and demand, economic viability, environmental, health, safety and socio-economic impacts, and taking into account the developmental requirements of the Southern African region. ${ }^{112}$ Furthermore, Act 34 of 2008 states that before finalising an integrated energy plan, the Minister of Energy must invite public comment and duly consider such comments. ${ }^{113}$

Act 34 of 2008 will now be assessed against the backdrop of the principles related to sustainable development contained in the New Delhi Declaration. In its preamble, Act 34 of 2008 makes note of the role renewable energy (as part of a diverse energy mix) could play in facilitating economic development and the eradication of poverty in South Africa. This relates to the New Delhi Declaration principle of equity and the eradication of poverty. ${ }^{114}$ The objectives related to the optimization and utilisation of energy supply call for the collection of data and information ${ }^{115}$ and the subsequent application of collected data and information to minimise the negative impacts

109 The importance lies in ensuring a diverse energy mix that is not only affordable and sustainable, but also contributes towards economic growth and poverty alleviation. See section 2 of the National Energy Act 34 of 2008.

110 These include: energy supply; transformation; transport; storage; and demand for energy. Section 6(2) of Act 34 of 2008.

111 The factors to be taken into consideration in drafting the integrated energy plan include: security of supply; economically available energy sources; affordability; universal accessibility and free basic electricity; social equity; employment; the environment; international commitments; consumer protection and contribution of energy supply to socio-economic development. Section $6(2)(a)-(j)$ of Act 34 of 2008.

112 Section 6(4)(a) - (f) of Act 34 of 2008.

113 Section 6(7)(a) - (b) of the National Energy Act, 34 of 2008.

114 Principle 2 of the New Delhi Declaration. See paragraph 2.2 above.

115 Section 2(f) of Act 34 of 2008. 
related to human health, safety and the environment. ${ }^{116}$ Act 34 of 2008 further states that any data or information collected for the purposes of drafting an integrated energy plan must be made available to the public in terms of the provisions of the Promotion of Access to Information Act and the Statistics Act 6 of 1999. ${ }^{117}$ With reference to these provisions, the ISDL principle of public participation and access to information and justice apply, ${ }^{118}$ while the provisions related to minimising the negative impacts related to energy carriers pertain to the principle of the precautionary approach to human health, natural resources and ecosystems. ${ }^{119}$ The principles to be applied in formulating the integrated resource plan envisaged by Act 34 of 2008 also relate closely to the New Delhi principles. In the first instance, the requirement that the South African government must ensure the optimal use of indigenous and regional energy resources ${ }^{120}$ relates directly to the duty resting on States to ensure the sustainable use of natural resources. ${ }^{121}$ It might be argued that the reference to regional resources in this section could be seen to infer that the principle of common but differentiated responsibilities ${ }^{122}$ should be considered in the formulation of a national integrated energy plan. This could possibly transcend the traditional paradigm of sovereign resource exploitation. ${ }^{123}$ The fact that the integrated energy plan is required to take into consideration economic viability and its possible environmental and social impacts ${ }^{124}$ relates to the ISDL principle of integration and interrelationship in relation to human health and social, economic and environmental objectives. ${ }^{125}$ Lastly, the provision requiring the Minister to invite public comment before promulgating an integrated energy plan relates to the principle of public participation and access to information and justice ${ }^{126}$ as well as to the principle of good governance. ${ }^{127}$

116 Section 2(h) and Section 4 of Act 34 of 2008.

117 Section 3 of the Act 34 of 2008.

118 Principle 5 of the New Delhi Declaration. See paragraph 2.5 above.

119 Principle 4 of the New Delhi Declaration. See paragraph 2.4 above.

120 Section 6(4)(b) of Act 34 of 2008.

121 Principle 1 of the New Delhi Declaration. See paragraph 2.1 above.

122 Principle 3 of the New Delhi Declaration. See paragraph 2.3 above.

123 See in general Schrijver "Sovereignty".

124 Section 6(4)(d) and (e) of Act 34 of 2008.

125 Principle 7 of the New Delhi Declaration. See paragraph 2.7 above.

126 Principle 5 of the New Delhi Declaration. See paragraph 2.5 above.

127 Principle 6 of the New Delhi Declaration. See paragraph 2.6 above. 229 / 569 
The provisions regarding the promulgation of a national integrated energy plan as contained in the National Energy Act 34 of 2008 have led to the drafting of the Integrated Resource Plan for Electricity, 2010 - 2030 (hereinafter referred to as the IRP) by the South African Department of Energy. The second revision of the IRP has been released for public commentary and has as yet not been promulgated into legislation. The IRP sets out the long-term plan envisaged by the South-African government in increasing the the provision of renewable energy as a contributor to the overall electricity supply of the country.

\subsection{South African legal developments relating to sustainable development}

Recent legal developments surrounding the formulation of a national strategy for sustainable development have shown the inclusion of SDL principles in resulting policy documents. This section will accordingly deal with contemporary national legal developments related to sustainable development and specifically focus on the principles underpinning the concept of sustainable development in the South African context. A slightly different methodology will be applied in this section, in as much as the principles contained in the national measures will be compared to the New Delhi principles in order to assess to what extent the national SDL principles resemble the international SDL principles.

3.5.1 The National Framework for Sustainable Development in South Africa, 2008 and the National Strategy and Action Plan for Sustainable Development, 2010 - 2014 
The mandate contained in the provisions of the $\mathrm{JPI}^{128}$ led to the adoption of the National Framework for Sustainable Development (NFSD) in 2008. The purpose of the NFSD is to enunciate South Africa's national vision for sustainable development and to specify strategic interventions in order to ensure a sustainable development path. $^{129}$

The adoption of the NFSD was the first step in mapping out the South African development path, with the next step being the formulation of a strategy and action plan for its implementation. To this end, the National Strategy and Action Plan for Sustainable Development, 2010 - 2014 (NSSD) contains South Africa's national sustainable development strategy and action plan. The sustainable development strategy relates to three key elements, namely directing the development path towards sustainability; ${ }^{130}$ changing behaviour, values and attitudes; ${ }^{131}$ and restructuring the governance system and building capacity. ${ }^{132}$ Giving effect to the strategic goals as set out by the strategy contained in the NSSD, the action plan refers to five strategic priorities, namely enhancing systems for integrated planning and implementation; sustaining our ecosystems and using natural resources efficiently; promoting economic development via investing in sustainable infrastructure; creating sustainable human settlements; and responding appropriately

128 Paragraph 162(b) states the importance of the formulation and elaboration of national strategies for sustainable development by 2005.

129 Executive summary of the National Framework for Sustainable Development, 20087.

130 The strategic goals related to this element of the national strategy include to reduce resource use as well as the carbon intensity of the economy; to provide equal access to resources and a decent quality of life for all citizens; and to ensure the effective integration of sustainability concerns into all policies, planning and decision-making at national, provincial and local levels. See paragraph 2.2.1 of the National Strategy for Sustainable Development, $2010-2014$.

131 Related strategic goals include to develop and promote new social and economic goals based on sustainability; to promote environmentally responsible behaviour through incentives and disincentives; to build a culture that recognises that socio-economic systems are dependent on and embedded within ecosystems; and to increase awareness and understanding of the value of natural resources (ecosystem services) to human wellbeing. See paragraph 2.2.2 of the National Strategy for Sustainable Development, 2010 - 2014.

132 Related strategic goals include to ensure effective integration and collaboration across all functions and sectors within government; to demonstrate commitment in changing the development focus to one based on sustainable programmes; to adopt a long-term view to development planning and implementation that takes cognisance of intergenerational equity; to adhere to and exercise principles of good and ethical governance; and to monitor, evaluate and report performance and progress in respect of sustainability goals. See paragraph 2.2.3 of the National Strategy for Sustainable Development, 2010 - 2014. 
to emerging human development, economic and environmental challenges (including climate change, rising oil prices, globalisation and trade). ${ }^{133}$

The NFSD contains the national vision for sustainable development, ${ }^{134}$ which is underpinned by a set of principles that must guide all decisions and actions taken to achieve this vision. This also includes any and all action taken in implementing the strategic goals and priorities comprising the national strategy and action plan provided for by the NSSD. The principles referred to in the NFSD resort under the headings of "first order" principles, ${ }^{135}$ "substantive" principles, ${ }^{136}$ and "process" principles. $^{137}$

The "first order" principles include human dignity and social equity, justice and fairness, and democratic governance. While the NFSD refrains from disclosing an in-depth definition of what each principle entails, it can be said that the "first order" principles relate chiefly to the fundamental human rights related to sustainable development. Accordingly, these "first order" principles relate to the New Delhi principles of equity and the eradication of poverty, ${ }^{138}$ public participation and access to information and justice, ${ }^{139}$ and good governance. ${ }^{140}$

The "substantive" principles include the efficient and sustainable use of natural resources, the development of socio-economic systems respectful of eco-systems,

133 See paragraph 2.1 of the National Strategy for Sustainable Development, $2010-2014$.

134 South Africa aspires to be a sustainable, economically prosperous and self-reliant nation state that safeguards its democracy by meeting the fundamental human needs of its people, by managing its limited ecological resources responsibly for current and future generations, and by advancing efficient and effective integrated planning and governance through national, regional and global collaboration. See Executive summary of the National Framework for Sustainable Development, 20088.

135 These principles relate to those fundamental human rights that are guaranteed in the Constitution, and underpin the very nature of our society and system of governance. See National Framework for Sustainable Development, 200820.

136 These principles address the content or conditions that must be met in order to have a sustainable society. They are predominantly based on sustainable development principles already enshrined in the National Environmental Management Principles, contained in section 2 of the National Environmental Management Act 107 of 1998. National Framework for Sustainable Development, 200820.

137 These principles apply specifically to the implementation of the national strategic framework and the subsequent national strategy and action plan. See National Framework for Sustainable Development, 200820.

138 Principle 2 of the New Delhi Declaration. See paragraph 2.2 above.

139 Principle 5 of the New Delhi Declaration. See paragraph 2.5 above.

140 Principle 6 of the New Delhi Declaration. See paragraph 2.6 above. 
and ensuring that the resources necessary for long-term survival are not destroyed for short-term gain. In comparing the "substantive" principles to the New Delhi principles, similarities become evident between the stated national principles and the international SDL principles of the duty of states to ensure the sustainable use of natural resources, ${ }^{141}$ which is closely related to common but differentiated responsibility; ${ }^{142}$ the precautionary approach to human health, natural resources and eco-systems; ${ }^{143}$ the integration and interrelationship principle $;^{144}$ and the principle of equity and the eradication of poverty. ${ }^{145}$

In the final instance, the "process" principles contained in the NFSD refer to integration and innovation, consultation and participation, and implementation in a phased manner. With reference to the New Delhi principles, the "process" principles relate to the SDL principles of integration and interrelationship, ${ }^{146}$ public participation and access to information and justice; ${ }^{147}$ and good governance. ${ }^{148}$

Drafted nearly a decade after the New Delhi Declaration, the NFSD identifies sustainable development principles which correlate in a large measure with the ISDL principles laid down by the New Delhi Declaration. The principles referred to in the NFSD provide for a national framework within which the formulation and implementation of law and policy can play an effective role in promoting sustainable development. The NFSD and the subsequent NSSD should therefore be seen as legal developments taking South Africa a step forward on the path towards sustainable development.

141 Principle 1 of the New Delhi Declaration. See paragraph 2.1 above.

142 Principle 3 of the New Delhi Declaration. See paragraph 2.3 above. The principle of common but differentiated responsibility is also reflected clearly in the wording of the NFSD's vision for national sustainable development, in as much as it refers to the importance of national, regional and global collaboration. See note 134 above.

143 Principle 4 of the New Delhi Declaration. See paragraph 2.4 above.

144 Principle 7 of the New Delhi Declaration. See paragraph 2.7 above.

145 Principle 2 of the New Delhi Declaration. See paragraph 2.2 above.

146 Principle 7 of the New Delhi Declaration. See paragraph 2.7 above.

147 Principle 5 of the New Delhi Declaration. See paragraph 2.5 above.

148 Principle 6 of the New Delhi Declaration. See paragraph 2.6 above. $233 / 569$ 


\section{Conclusion}

The correlation between the advantages connected with the implementation of renewable energy and the promotion of sustainable development is universally recognised. ${ }^{149}$ Following this global trend, various South African regulatory measures draw the link between increasing access to affordable renewable energy and development in the social, economic and environmental spheres, in other words - sustainable development. ${ }^{150}$ The effective regulation of the implementation of renewable energy in South Africa necessitates the formulation of similarly effective law and policy focused on sustainable development. ${ }^{151}$ It is argued that, in order to effect sustainable development, the relevant law and policy should conform to the principles contained in the international sustainable development law enunciated in the New Delhi Declaration. ${ }^{152}$

The New Delhi Declaration contains seven principles of international law which support the balanced integration of law and policy related to sustainable development. ${ }^{153}$ These principles should therefore be used as the starting point in a principled assessment of the efficacy of the formulation process and the subsequent national renewable energy law and policy designed to promote sustainable development. ${ }^{154}$ In assessing the extent to which the South African renewable energy policy gives effect to the principles contained in the New Delhi Declaration and sustainable development as the overarching objective of the policy, the formulation process was discussed, as well as the resulting regulatory measures. ${ }^{155}$

The discussion of the South African law and policy relating to renewable energy and the national sustainable development legal developments shows that the regulatory measures comprising the law and policy contain and/or refer, either directly or indirectly, to all seven of the New Delhi principles. It was, however, never the intention of the author to use principled criteria to "make best policy the enemy of the

149 See paragraph 1 above.

150 See paragraph 1 above.

151 See paragraphs 1 and 3.5 above.

152 See paragraph 1 above.

153 For a discussion of the principles contained in the New Delhi Declaration, see paragraphs 2.1 to 2.7 above.

154 See paragraph 1 above.

155 See paragraph 3 above. 
good"156 but rather to assess the manner in which principled law and policy can serve to promote sustainable development.

Having applied the principled assessment described in the methodology in the South African context, the conclusion can be reached that the national renewable energy law and policy may be described as a viable reaction to sustainable development challenges. Furthermore, the principled assessment of national law and policy has shown that the New Delhi principles, though originally defined for international law, have the potential to serve as an ideal norm against which to test law and policy on any governance level. 


\section{Bibliography}

\section{Books}

Aguis "Obligations of Justice"

Aguis E "Obligations of Justice Towards Future Generations: A Revolution on Social and Legal Thought" in Aguis E et al (eds) Future Generations and International Law (London Earthscan Publications 1998) 51 - 63

Cordonier Segger and Khalfan Sustainable Development Law

Cordonier Segger MC and Khalfan AL Sustainable Development Law:

Principles, Practices and Prospects (Oxford University Press 2004)

French International Law and Policy

French D International Law and Policy of Sustainable Development (Manchester University Press, 2005)

Gehring MW and Cordonier Segger MC Sustainable Development in World Gehring MW and Cordonier Segger MC Sustainable Development in World Trade Law (Kluwer Law International, Netherlands, 2005)

Lowe Sustainable Development

Lowe V "Sustainable Development and Unsustainable Arguments" in Boyle A and Freestone D International Law and Sustainable Development: Past Achievements and Future Challenges (Oxford University Press, 1999)

Rosenau Along the Domestic-Foreign Frontier

Rosenau JN Along the Domestic-Foreign Frontier: Exploring Governance in a Turbulent World 1st ed (Cambridge University Press 1997)

Sands Principle of International Environmental Law

Sands P Principles of International Environmental Law: Frameworks, Standards and Implementation 2nd ed (Cambridge University Press 2005). 
Scrijver Rights and Duties

Schrijver NJ Permanent Sovereignty over Natural Resources: Balancing Rights and Duties (Cambridge University Press 1997)

Schrijver "Sovereignty"

Schrijver NJ "Permanent Sovereignty over Natural Resources" in Wolfrum R (ed) Max Planck Encyclopedia of Public International Law (Oxford University Press 2010).

\section{Cases}

Case Concerning the Gabcikovo-Nagymaros Project 1997 ICJ 78140

\section{Contributions at Conferences}

Bazilian M and Nussbaumer P "UNIDO Contribution to the 4th UN Conference on LDCs Energy Services" (Background Paper delivered at the 4th UN Conference on LDCs Energy Services in Istanbul, Turkey 9 - 13 May 2011) available at http://www.unohrlls.org/UserFiles/File/UNIDO\%20Contribution\%20on\%20LDC\%20IV \%20Energy\%20Services.pdf.

Karakezi S, Lata K and Coelho ST "Traditional Biomass Energy Improving its Use and Moving to Modern Energy Use" (Thematic Background Paper delivered at the International Conference for Renewable Energies in Bonn 2004) available at http://www.ren21.net/Portals/97/documents/Bonn\%202004\%20$\% 20$ TBP/Traditional\% 20Biomass\%20Energy.pdf. 


\section{International legal instruments}

Bali Action Plan, UNFCCC, Decision 1/CP.13

Cancun Agreements, UNFCCC, Decision 1/CP.16

Committee on Economic, Social and Cultural Rights, Poverty and the International Covenant on Economic, Social and Cultural Rights, UN ESCOR, 2001, UN Doc E/C.12/2001/10

Copenhagen Accord, UNFCCC, Decision 2/CP.15

Declaration on the Right to Development, GA Res. 41/128, UN GAOR, 1986 Supp. No. 53, U.N. Doc. A/41/53, 186 (1986)

International Covenant on Economic, Social and Cultural Rights, 19 December 1966, 999 U.N.T.S. 3

Johannesburg Plan of Implementation, Report of the World Summit on Sustainable Development, Johannesburg, South Africa, 4 September 2002, UN Doc.

A/CONF.199/20

Millennium Declaration, G.A. Res. 55/9, UN GAOR, 2000, c. III

New Delhi Declaration of Principles of International Law relating to Sustainable Development, ILA Resolution 3/2002

Office of the High Commissioner for Human Rights, The role of good governance in the Promotion of Human Rights, Commission on Human Rights Resolution 2001/72

Rio Declaration on Environment and Development, Report of the United Nations Conference on Environment and Development, UN Doc. A/CONF.151/6/Rev.1, (1992) 31 I.L.M. 874 
Stockholm Declaration of the United Nations Conference on the Human

Environment, 16 June 1972, UN Doc. A/CONF.48/14/Rev.1, 11 I.L.M. 1461 (1972)

United Nations Convention on Biological Diversity, 5 June 1992, 1760 U.N.T.S. 79, 31 I.L.M. 822

United Nations Convention to Combat Desertification in Countries Experiencing Serious Drought and/or Desertification, Particularly in Africa, 17 June 1994, 33 I.L.M. 1328

United Nations Framework Convention on Climate Change, 9 May 1992, 31 I.L.M. 849

Universal Declaration of Human Rights, G.A. Res. 217(III), UN GAOR, 3d Sess., Supp. No. 13, U.N. Doc. A/810 (1948)

\section{Internet sources}

Hepburn and Ahmed 2002 www.cisdl.org/pdf/brief_common.pdf Hepburn $\mathrm{J}$ and Ahmed I The Principle of Common but Differentiated Responsibilities: Origins and Scope Centre for International Sustainable Development Law Legal Brief www.cisdl.org/pdf/brief_common.pdf [date of use 1 Nov 2011]

Anon www.eia.gov/cabs/South_Africa [date of use 1 Nov 2011] 


\section{Journal articles}

Cordonier Segger United Nations Sustainable Development Journal

Cordonier Segger MC "Significant Developments on Sustainable Development Law and Governance: A Proposal" 2004 United Nations Sustainable

Development Journal Vol 28 Issue 161 - 74

Goepel 2010 Sustainability

Goepel M "Formulating Future Just Policies: Applying the Delhi Sustainable Law Principles" 2010 Sustainability 21694 - 1718

Goldemberg and Coelho 2004 Energy Policy

Goldemberg J and Coelho ST "Renewable energy - traditional biomass vs modern biomass" 2004 Energy Policy 32711 - 714

Hickey and Walker 1995 Virginia Environmental Law Journal

Hickey,Jr JE and Walker VR "Refining the Precautionary Principle in International Environmental Law" 1995 Virginia Environmental Law Journal $14423-454$

Sands 1994 British Yearbook of International Law

Sands P "International Law in the Field of Sustainable Development" 1994 British Yearbook of International Law 338 - 348

Winkler 2005 Energy Policy

Winkler $\mathrm{H}$ "Renewable energy policy in South Africa: policy options for renewable electricity" 2005 Energy Policy 3327 - 38 


\section{Legislation, policy documents and government publications}

Biofuels Industrial Strategy for the Republic of South Africa of 2006

2008 Revision of the National Energy Efficiency Strategy of the Republic of South-

Africa of 2005 GN 908 in GG 32342 of 26 June 2009

Carbon Tax Policy Paper of 2010

Constitution of the Republic of South-Africa, 1996

Electricity Regulation Act 4 of 2006

Independent System and Market Operator Establishment Bill GN 290 in GG 34289

of 13 May 2011

Integrated Resource Plan for Electricity 2010-2030 Revision 2

Medium Term Risk Mitigation Project for Electricity in South Africa (2010 - 2016)

National Climate Change Response Green Paper of 2010

National Climate Change Response White Paper of 2011

National Framework for Sustainable Development in South Africa, 2008

National Treasury Draft Policy Paper on Market Based Instruments of 2006

National Energy Act 34 of 2008

National Energy Regulator Act 40 of 2004

National Environmental Management Act 107 of 1998

National Strategy and Action Plan for Sustainable Development, 2010 - 2014

Renewable Energy Feed-in-Tariff Regulatory Guidelines of 2009

Renewable Energy Independent Power Producer Programme (2011)

White Paper on Renewable Energy of 2003

White Paper on the Energy Policy of the Republic of the Republic of South-Africa of 1998 


\section{Reports by international organizations}

Bottriel CISDL Draft Working Paper

Bottriel K and Cordonier Segger MC The Principle of Public Participation and Access to Information and Justice Centre for International Sustainable

Development Law Draft Working Paper (Oxford 2005)

Brundtland Our Common Future

World Commission on Environment and Development, Our Common Future (Oxford: Oxford University Press 1987)

Chowdbury N and Skarstedt CE The Principle of Good Governance CISDL Draft Working Paper

Chowdbury N and Skarstedt CE The Principle of Good Governance Centre for International Sustainable Development Law Draft Working Paper (Oxford 2005)

Cordonier Segger MC and Rana R Selecting Best Policies and Laws for Future Generations CISDL Working Paper

Cordonier Segger MC and Rana R Selecting Best Policies and Laws for Future Generations Centre for International Sustainable Development Law Working Paper and Worked Examples (Montreal Canada, 2008)

Hepburn and Khalfan CISDL Working Draft Paper

Hepburn $\mathrm{J}$ and Khalfan AL The Principle of Equity and the Eradication of Poverty Centre for International Sustainable Development Law Centre for International Sustainable Development Law Draft Working Paper (Oxford 2005).

Hepburn J, Cordonier-Segger MC and Gehring M The Principle of the Precautionary Approach to Human Health, Natural Resources and Ecosystems Centre for International Sustainable Development Law Draft Working Paper 
Hepburn J, Cordonier-Segger MC and Gehring M The Principle of the Precautionary Approach to Human Health, Natural Resources and Ecosystems Centre for International Sustainable Development Law Draft Working Paper (Oxford 2005).

Jodion CISDL Draft Working Paper 2005

Jodion S The Principle of Integration and Interrelationship in Relation to Human Rights and Social, Economic and Environmental Objectives Centre for International Sustainable Development Law Draft Working Paper (Oxford 2005).

The Energy Access Situation in Developing Countries: A Review focusing on the Least Developed Countries and Sub-Saharan Africa UNDP and WHO 2009

The Energy Access Situation in Developing Countries: A Review focusing on the Least Developed Countries and Sub-Saharan Africa UNDP and WHO 2009 available at www.undp.org

United Nations, Report of the Expert Group Meeting on Identification of Principles in International Law for Sustainable Development (UN Secretariat, September 1995). 